\title{
Spatial and Seasonal Variation of Diatom Assemblages Composition in a Partly Polluted River
}

\author{
Kazuhiro KaтоH
}

\begin{abstract}
Environmental factors affecting the species composition of periphytic diatom assemblages were analyzed in the partly polluted Asa River, in Tokyo, Japan, using principal component analysis, individual differences scaling and direct gradient analysis. The effects of water pollution, seasonal change of temperature, and substrate were detected, among which pollution was the most influential in this river. Substrate had only a little effect. The existence of both direct and indirect effects (through water quality and temperature) was suggested.
\end{abstract}

Key words: diatom, individual differences scaling, multivariate analysis, pollution

\section{Introduction}

The aim of this study is to determine the environmental factors influencing the species composition of periphytic diatom assemblages in a partly polluted, typically suburban river in Japan. It is well known that diatom assemblages in rivers vary spatially and temporally. Spatial variation is sometimes caused by environmental degradation such as water pollution (LANGE-Bertalot, 1978) and acidification (LAMPKin and Sommerfeld, 1982), or by variations in natural conditions such as substrate (Tuchman and Stevenson, 1980; Stevenson, 1983) and light intensity (Sternman and McInTIRE, 1986). Although the effects of these causes have been studied by both experimental methods e.g., using laboratory streams, and field surveys, it is difficult to know which factor is more important to diatom assemblages in a specific natural water. To answer this kind of question, multivariate analysis of ecological data is appropriate.

Multivariate analyses are being used increasingly in studies of ecological communities (Kent and Ballard, 1988). As for studies of diatoms, multivariate methods have been used by many authors to detect the effects of various environmental factors, such as acidity (Huttunen and Merilainen, 1983), concentration of nutrients (VARIS et al., 1989), temperature (WEHR, 1981), conductivity (F LOWER and Nicolson, 1987), and water pollution (Descy, 1979; Chessman, 1986). Multivariate analysis comprises a large number of methods (GAuch, 1982; Digby and Kempton, 1986; Ludwig and RAYNolDS, 1988). Different methods have been recommended by different authors as useful to analyze community structure, e.g., detrended correspondence analysis (DCA; HILL and GAUCH, 1980) by GaUCH (1982), canonical correspondence analysis (CCA; Ter Brank, 1986) by Noest et al. (1989), and multidimensional scaling (MDS) by MiNCHIN (1987). Principal component analysis (PCA) is also popular (KENT and BALLARD, 1988) and said to be effective (Feoli and Feoli-Chiapella, 1980).

Therefore, before this study, I examined the suitability of several methods, such as cluster analysis, PCA, principal coordinate analysis, reciprocal averaging (HiLl, 1973), MDS, and individual differences scaling (INDSCAL). (There was no chance to use DCA and CCA.) PCA turned out to be the most effective for the purpose of this study; only PCA distinguished all three environmental factors and revealed 
the association among the factors and species. The often-criticized distortion of PCA (CLYMo, 1980; GAUCH, 1982) was not negligible in this study, but it did not make difficult the interpretation of the results. To characterize the major species, direct gradient analysis was also used (see Gauch, 1982). In addition, the output of INDSCAL will be mentioned, since it created some unique results.

The results of PCA derived from the preliminary data (120 samples) were reported previously (КАтOH, 1988), but in a somewhat flawed study. The arch-shaped distortion among the principal components, for example, was not shown and analyzed, nor were the meanings of each of the principal components clear enough, because the analysis and the evaluation of the component scores were not sufficient. Improvements are therefore called for, and it appeared that more reliable values, especially the ratio of contribution of each principal component, can be obtained from analysis of the full data. Additional methods, such as INDSCAL, can reveal more details as well. In this paper, new results obtained by the improved analysis or newly adopted methods applied to full data set are described.

\section{Materials and methods}

\section{2-1. Study sites}

Fifteen sampling stations were set up along the Asa River and its tributaries. The Asa is a branch of the Tama River, and runs west of Tokyo, with a main flow length of about $30 \mathrm{~km}$.
The upper part of the watershed is covered with afforested conifer trees in the Station 1 area. The lower part is a residential area where the river is considerably polluted. Stations 7 to 15 were established in this area, while Stations 2 to 6 were set up in the intermediate area. More details and a map are given in $\mathrm{K}_{\mathrm{ATOH}}$ (1988). Station 16 in Катон (1988) was omitted in the present study, because the field survey in July, 1987 at this station was not carried out because of a shower. Missing values may distort the results of principal component analysis and make the use of INDSCAL almost impossible.

\section{2-2. Field surveys and sample treatment}

Field surveys were conducted bimonthly from November, 1986 to September, 1987 (six surveys). Of the two samples collected in each station, one was from the upper surface of stones and the other from dead leaves. Water conditions listed in Table 1 were recovered at all stations. In the laboratory, samples were cleaned with $\mathrm{H}_{2} \mathrm{SO}_{4}$ and mounted in pleurax. The relative abundance of diatom taxa occurring in each sample was obtained by counting the number of individuals under a light microscope at a magnification of $1500 \mathrm{x}$. Over 400 valves were counted for each sample.

\section{2-3. Data analysis}

The original data of diatoms consisted of 173 taxa. To reduce the number of zero entry and to make the data set compact, forty-one taxa whose maximum relative abundance in all the samples was larger than $3 \%$ were selected as variables (Table 2). Factor loadings and prin-

Table 1. Measured water conditions and their average values.

\begin{tabular}{lccccc}
\hline & \multicolumn{4}{c}{ Average values } \\
\cline { 3 - 5 } Water conditions & All & Sta. 1 & Sta. 2-6 & Sta. 7-15 \\
\hline Chemical oxygen demand $(\mathrm{COD})\left(\mathrm{mgO}_{2} \cdot \mathrm{l}^{-1}\right)$ & 4.47 & 0.87 & 2.31 & 6.07 \\
Electric conductivity $(\mathrm{EC})\left(\mu \mathrm{S} \cdot \mathrm{cm}^{-1}\right)$ & 271 & 92.4 & 152 & 357 \\
Water temperature $\left({ }^{\circ} \mathrm{C}\right)$ & 20 & 13 & 17 & 22 \\
$\mathrm{pH}$ & 6.9 & 6.3 & 6.5 & 7.2 \\
$\mathrm{NH}$ & 3.49 & 0.02 & 0.44 & 5.57 \\
$\mathrm{NO}_{4}-\mathrm{N}\left(\mathrm{mg} \cdot \mathrm{l}^{-1}\right)$ & 0.18 & 0.03 & 0.04 & 0.27 \\
$\mathrm{NO}_{3}-\mathrm{N}\left(\mathrm{mg} \cdot \mathrm{l}^{-1}\right)$ & 2.56 & 1.14 & 1.86 & 3.10 \\
$\mathrm{PO}_{4}-\mathrm{P}\left(\mathrm{mg} \cdot \mathrm{l}^{-1}\right)$ & 0.28 & 0.01 & 0.11 & 0.40 \\
$\mathrm{SiO}_{2}-\mathrm{Si}\left(\mathrm{mg} \cdot \mathrm{l}^{-1}\right)$ & 6.87 & 5.41 & 6.45 & 7.27 \\
\hline
\end{tabular}


Table 2. The list of the analyzed 41 taxa and their average relative abundance (\%).

\begin{tabular}{|c|c|c|c|c|}
\hline \multirow[b]{2}{*}{ Taxon } & \multicolumn{4}{|c|}{ Average relative abundance } \\
\hline & $\begin{array}{l}\text { All } \\
\text { stations }\end{array}$ & Sta. 1 & Sta. $2-6$ & Sta. 7-15 \\
\hline Achnanthes clevei & 0.4 & 5.3 & 0.2 & 0.0 \\
\hline A. convergens & 0.8 & 4.4 & 1.4 & 0.0 \\
\hline A. krasskei & 0.3 & 2.1 & 0.3 & 0.0 \\
\hline A. lanceolata & 3.2 & 9.2 & 6.4 & 0.7 \\
\hline A. lanc. var. elliptica & 0.4 & 1.5 & 0.7 & 0.2 \\
\hline A. minutissima & 0.8 & 4.8 & 1.2 & 0.1 \\
\hline A. min. var. saprophila & 2.4 & 0.0 & 0.2 & 3.9 \\
\hline A. subhudsonis & 0.3 & 2.5 & 0.4 & 0.0 \\
\hline Cocconeis pediculus & 0.5 & 0.0 & 1.3 & 0.1 \\
\hline C. placentula & 4.8 & 12.7 & 10.9 & 0.5 \\
\hline Cyclotella meneghiniana & 1.3 & 0.0 & 0.4 & 1.9 \\
\hline Cymbella minuta & 1.0 & 1.6 & 2.6 & 0.1 \\
\hline C. sinuata & 0.2 & 0.2 & 0.4 & 0.1 \\
\hline Diatoma mesodon & 0.2 & 1.8 & 0.1 & 0.0 \\
\hline Fragilaria capucina & 0.5 & 4.0 & 0.4 & 0.1 \\
\hline F. construens & 1.0 & 0.2 & 2.5 & 0.3 \\
\hline$F$. constr. var. venter & 0.8 & 0.1 & 2.0 & 0.3 \\
\hline F. vaucheriae & 0.3 & 0.1 & 0.8 & 0.1 \\
\hline Gomphonema angustum & 0.3 & 0.2 & 0.9 & 0.1 \\
\hline G. parvulum & 8.7 & 0.1 & 1.9 & 13.5 \\
\hline G. pseudoaugur & 0.5 & 0.0 & 0.2 & 0.8 \\
\hline G. quadripunctatum & 0.4 & 0.3 & 1.0 & 0.0 \\
\hline Melosira ambigua & 0.1 & 0.0 & 0.2 & 0.1 \\
\hline M. varians & 1.2 & 8.3 & 1.4 & 0.2 \\
\hline Meridion circulare var. constricta & 0.2 & 2.2 & 0.2 & 0.0 \\
\hline Navicula atomus & 2.0 & 0.0 & 1.7 & 2.4 \\
\hline N. cryptocephala & 2.4 & 1.4 & 4.0 & 1.7 \\
\hline N. gregaria & 2.0 & 1.0 & 4.7 & 0.6 \\
\hline$N$, minima & 5.2 & 0.3 & 1.5 & 7.8 \\
\hline N. pupula & 1.2 & 0.3 & 0.1 & 1.9 \\
\hline N. saprophila & 0.3 & 0.0 & 0.5 & 0.3 \\
\hline N. seminulum & 2.5 & 0.1 & 0.7 & 3.7 \\
\hline N. subminuscula & 5.7 & 0.0 & 0.7 & 9.2 \\
\hline N. veneta & 0.7 & 0.7 & 1.0 & 0.5 \\
\hline Nitzschia amphibia & 5.2 & 0.0 & 4.6 & 6.1 \\
\hline N. dissipata & 3.5 & 2.1 & 10.0 & 0.1 \\
\hline N. hantzschiana & 9.3 & 0.8 & 13.8 & 7.8 \\
\hline N. linearis. & 1.8 & 9.3 & 3.1 & 0.2 \\
\hline N. palea & 21.6 & 1.5 & 8.2 & 31.2 \\
\hline Rhoicosphenia abbreviata & 0.5 & 1.1 & 1.2 & 0.0 \\
\hline Synedra ulna & 2.5 & 9.6 & 2.5 & 1.7 \\
\hline
\end{tabular}

cipal component scores were calculated from the correlation matrix of the log-transformed relative abundances of the taxa. The meanings of the principal component scores were analyzed by making scatter diagrams between the scores and the measured environmental conditions, and box plots of the scores. The values except water temperature (WT) were log-transformed, and the moving averages of the values measured in two successive surveys 
were calculated. As for the first survey (November, 1986), the values measured in the previous survey conducted in September, 1986 were used to obtain the moving average. This average was used in the present study, because it is assumed that diatom assemblages reflect their environmental conditions throughout their life about one or two months in assemblages with many cells (Watanabe and Suzuki, 1989; Tanaka and Watanabe, 1990), and because it was reported that the species composition may change more or less after the change of environmental conditions (Fukushima et al., 1986).

Each taxon was characterized by the factor loadings and further with direct gradient analysis (Gauch, 1982). Factor loadings mean the correlation coefficients between principal component scores and original variables. Factor loadings were calculated by this equation:

$$
r\left(z_{i}, x_{j}^{\prime}\right)=\left(\lambda_{i}\right)^{1 / 2} l_{i, j}
$$

$r\left(z_{i}, x_{j}\right)$ is factor loadings of $j$-th standardized variable $\left(x_{j}{ }_{j}\right)$ on $i$-th principal component. $\lambda_{i}$ and $l_{i, j}$ are $i$-th eigenvalue and $j$-th element of $i$-th eigenvector of the correlation matrix of the original variables, respectively.

Individual differences scaling was then applied to the data on relative abundance. Dissimilarity matrices between stations were calculated using Bray-Curtis index (BRAy and CurTis, 1957; see Bloom, 1981) for each sampling period and individual substrate type. Twelve dissimilarity matrices were obtained, and then the configuration of the stations and the weight vectors for all the dissimilarity matrices, i.e., the configuration of the sampling periods and substrata, were calculated using the $C$ program, INDS3WAY (Imalzumi and OKada, 1990). As for the application of INDSCAL to ecological data, see Oksanen and Hutrunen (1989).

\section{Results}

Figure $1 \mathrm{a}$ is a scatter plot matrix of the principal component scores. Arch-shaped three-dimensional distortion is easily seen. Figure $1 b$ shows the result of fitting a surface through the plots by least squares. The valley- shaped surface reflects the most important variation in species composition at least in the first three principal components, and the a)

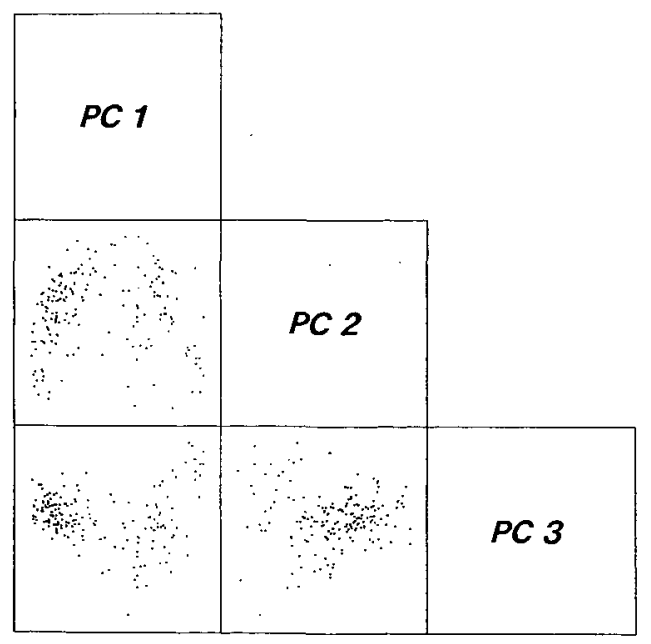

b)

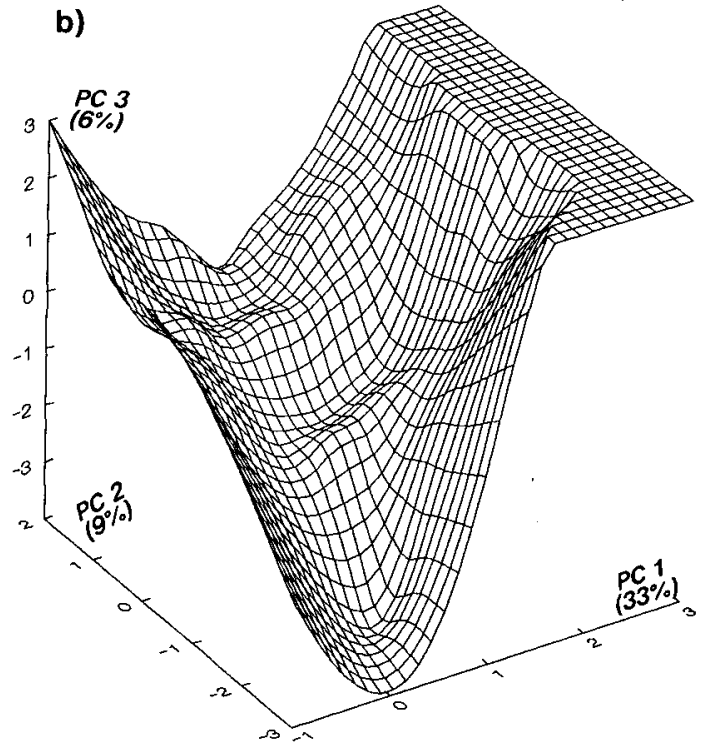

Fig. 1. The configuration of samples in the three dimensional space of the first, the second and the third principal components (PC's). a) Scatter plots matrix. b) The result of fitting a surface through the plots by least squares. The proportion of the eigenvalue of each PC is shown. 
secondary important variation is reflected at least in both the second and the third components.

The first principal component is apparently connected with water pollution (Fig. 2a). Scatter diagrams (not shown) of the first component score and some other water conditions (COD, $\mathrm{NH}_{4}-\mathrm{N}, \mathrm{NO}_{2}-\mathrm{N}$ and $\mathrm{PO}_{4}-\mathrm{P}$ ) were very similar to Figure 2a (correlations between EC and each of these conditions were: $r=0.67-0.87$, in log-transformed data). Figure $2 \mathrm{~b}$ is box plots of the first principal component score in each station. This figure shows that Station 1 was the cleanest and stations 7 to 15 the most polluted.

Although the second principal component is distorted (Figs. 1a, 1b), it can refer to the seasonal change of diatom assemblages. Figure 3a shows that the second principal component has a correlation with the moving average of water temperature $(r=0.60)$. Data of lesspolluted stations show a stronger correlation $(r=0.80, n=98)$. Figure $3 \mathrm{~b}$ is box plots of the second principal component scores in each sampling period. This figure shows that the second principal component score varies seasonally, from minimum in March to maximum in September.

a)

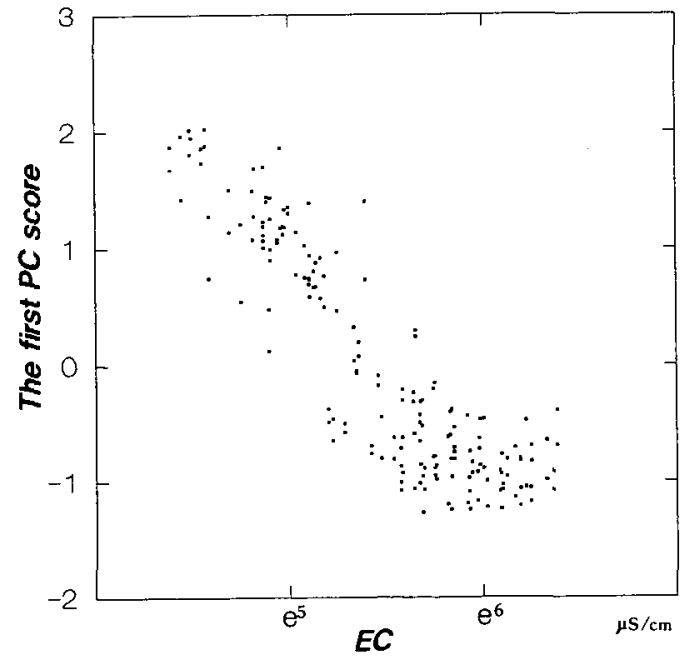

The effect of substrate can be seen in the first, second, and fourth components (Table 3). Both Wilcoxon signed rank test and simple sign test (see Sokal and Rohlf, 1981) supported this result. Figure 4 is box plots of the fourth principal component scores of the substrata.

The characterization of the species is shown in Figure 5a, which is a scatter diagram of the factor loadings of the first and second components. It is apparently horse-shoe shaped. Thus, that to evaluate the second axis, it is necessary to divide the plain along the first axis and then to evaluate the second axis separately within each division as shown in Figure $5 \mathrm{~b}$. This figure indicates the pollution tolerance and the seasonality of the studied taxa. The results of direct gradient analysis indicate that Figure $5 \mathrm{a}$ represents the real characteristics of each taxon (Fig. 6). Averaging operation was carried out to avoid the misunderstandings caused by the non-uniform distribution of the data.

Among the major diatom taxa in the Asa River, Cocconeis placentula EHr. was typically oligosaprobic and dominant in summer, while Nitzschia dissipata (Kütz.) Grun. was a typical oligosaprobic species and dominant in winter. It will be helpful to know that in Stations 2-6,

b)

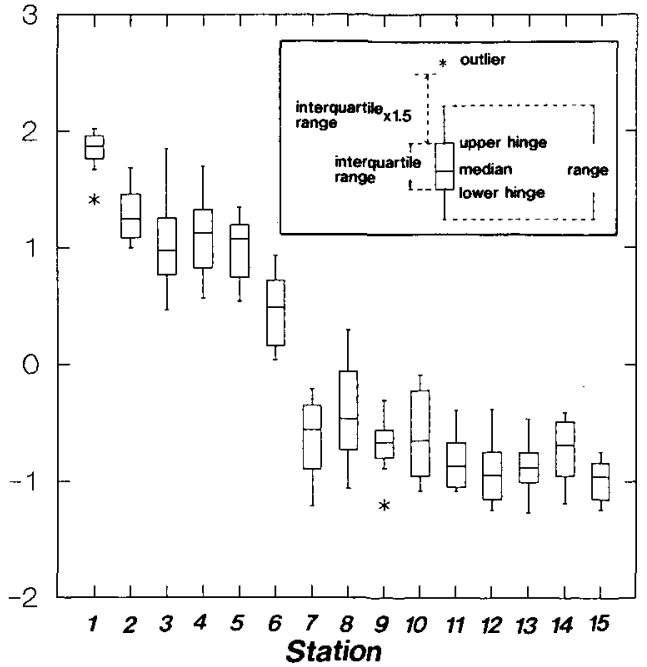

Fig. 2. a) The scatter diagram of the first principal component (PC) score and the moving average of log-transformed EC. b) The box plots of the first PC scores at each station. 
a)

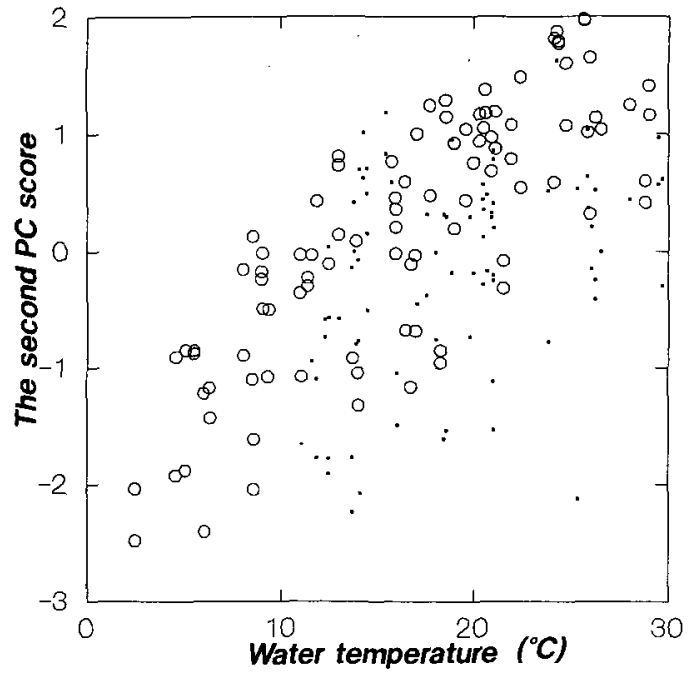

b)

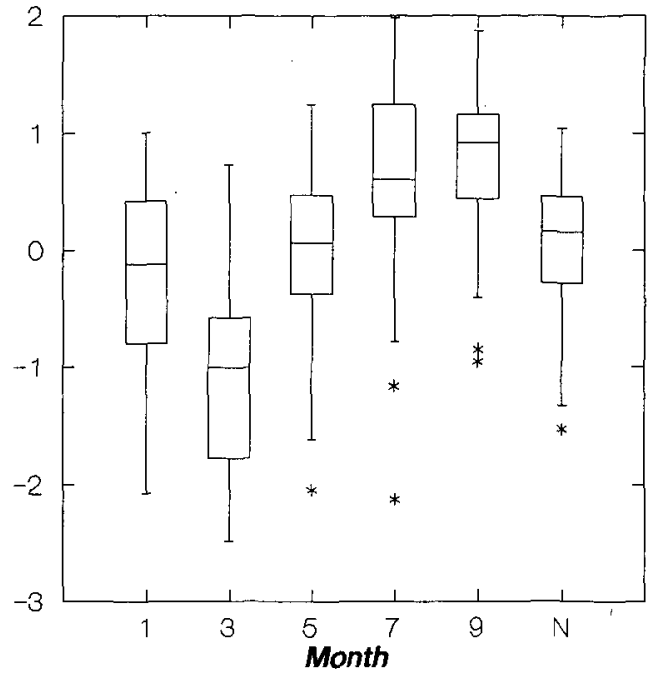

Fig. 3. a) The scatter diagram of the second principal component (PC) score and the moving average of water temperature. Open circles indicate samples of which the first PC score is more than $-0.5(r=0.80, n=98)$. Dots indicate samples of which the first PC score is -0.5 or smaller $(r=0.37, n=82)$. b) The box plots of the second PC scores in each month. "N" means November, 1986, and 1, 3, 5,7 and 9 mean January, March, May, July and September, 1987, respectively.

Table 3. The difference in the principal component (PC) scores caused by substrate.

\begin{tabular}{|c|c|c|c|c|c|}
\hline The order of PC & 1 & 2 & 3 & 4 & 5 \\
\hline \multicolumn{6}{|l|}{ Sign test } \\
\hline$x^{2}$ & 20.5 & 15.2 & 2.50 & 28.9 & 1.88 \\
\hline Significance ${ }^{1}$ & $* *$ & $* *$ & NS & $* *$ & NS \\
\hline \multicolumn{6}{|l|}{ Wilcoxon's test } \\
\hline$t_{s}$ & 5.63 & 4.08 & 2.12 & 6.07 & 2.07 \\
\hline Significance $^{1}$ & $* *$ & $* *$ & $*$ & $* *$ & $*$ \\
\hline Average difference $^{2}$ & 0.20 & 0.40 & 0.18 & 0.66 & 0.19 \\
\hline S. D. of difference & 0.28 & 0.83 & 0.70 & 0.87 & 0.97 \\
\hline
\end{tabular}

${ }^{1}$ NS, $P>0.05$ (not significant); $*, P<0.05 ; * *, P<0.01$

${ }^{2}$ The difference between $\mathrm{PC}$ score of dead-leaf samples and that of stone samples.

dominant species were $C$. placentula in summer and autumn, $N$. dissipata in winter, and $N$. hantzschiana RABN. in spring.

Individual differences scaling shows that the effect of substrate is quite small compared with that of the seasonal change (Fig. 7a). It also indicates that the configuration of the stations changes seasonally. In September, the differ. ence between Stations 1-6 and Stations 7-15 is obvious: the weight of the axis 2 was little (Fig. 7a) and the configuration of the stations indicated in Figure $7 \mathrm{~b}$ was evaluated along the axis 1. While, in March, Station 1, Stations 25 and Stations 6-15 are clearly separated because the weight of the axis 1 was little (Fig. $7 a)$.

\section{Discussion}

The previous study (КАтоH, 1988) has shown that water pollution is the most important fac- 


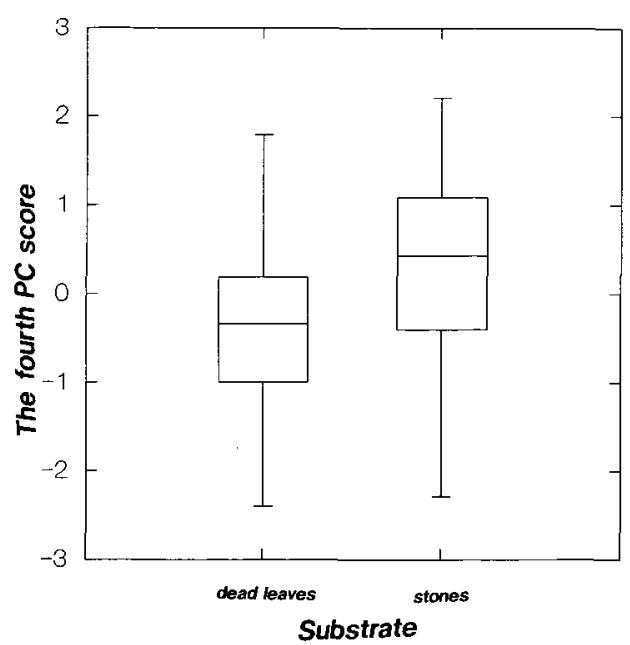

Fig. 4. The box plots of the fourth PC scores in each substrate.

tor for the species composition of periphytic diatom assemblages in the Asa River. In the present study, the first axis of PCA explained about $33 \%$ of the observed variation of species composition and represented the effecct of water pollution, and the first principal component score has the characteristics of a pollution index in this river. Examining Figure $2 b$ and Figure $7 \mathrm{~b}$ from this standpoint, it is apparent that the configuration of the sampling stations in Figure $7 \mathrm{~b}$ reflects the degree of water pollution. Diatom assemblages in Station 6 were similar to those in Stations 1-5 in summer and similar to those in Stations 7-15 in winter (Figs. $7 \mathrm{a}$ and $7 \mathrm{~b}$ ), and Station 6 was a moderately polluted region (Fig. $2 \mathrm{~b}$ ). It seems, therefore, that in the moderately polluted part of rivers, the water conditions deteriorate in winter. The reason for this is not clear in this study, but, generally, the decrease of flow amount in winter would increase the concentration of some pollutants, such as $\mathrm{NH}_{4}-\mathrm{N}$ (IcHIKawA, 1980). More frequent measurement of water conditions is necessary to confirm this.

There has been little research done on the seasonal variation in species composition of diatom assemblages [but see Bothwell (1988) for seasonal variation in growth rate, and see Muller-Haeckel and HÁkAnsson (1978) for immigration and emigration]. In previous works, water temperature, light intensity, and nutrient dynamics have been discussed in relation to the seasonal change of algal community (Muller-Haeckel and Håkansson, 1978; Wehr, 1981; Bothwell, 1988; Sabater, 1990). In the present study, the change of water temperature seemed to be the main cause of the seasonal change in species composition of diatom assemblages. However, it must be noted that the effect of water temperature on diatom assemblages is more apparent in less polluted waters (see Fig. 3a).

Except for a few studies (Tuchman and Stevenson, 1980; Stevenson, 1983), most authors have concluded that the difference of substrate does not cause variation in species composition (Millie and Lowe, 1983; Reiter, 1989; Watanabe and Suzuki, 1989). However, the present study, with sign test and Wilcoxon's test, suggests that differences in substrate have both their own effects (Fig. 4) and indirect effects through water quality and water temperature (Table 3 ). The result of individual differences scaling shows that the variation in species composition caused by these effects was much less than the seasonal change. Therefore, it is concluded that a difference in substrate causes little variation in species composition; it may even be negligible in some cases, especially in studies using multivariate methods.

One criticism of this approach may be that dead leaves flowed down from the upper part of the river so that assemblages attached to them merely reflect the environment of the upper stream where pollution is not severe. But the facts that assemblages on dead leaves developed under warmer conditions as the second principal component score indicated, and that water is cooler in the upper part of a river, argue strongly against this possibility.

\section{Acknowledgements}

I would like to express my thanks to Prof. T. Matsumoto, College of Arts and Sciences, the University of Tokyo, for continuing guidance, and to Prof. K. Watanuki, College of Arts and Sciences, the University of Tokyo, for his assis- 
a)

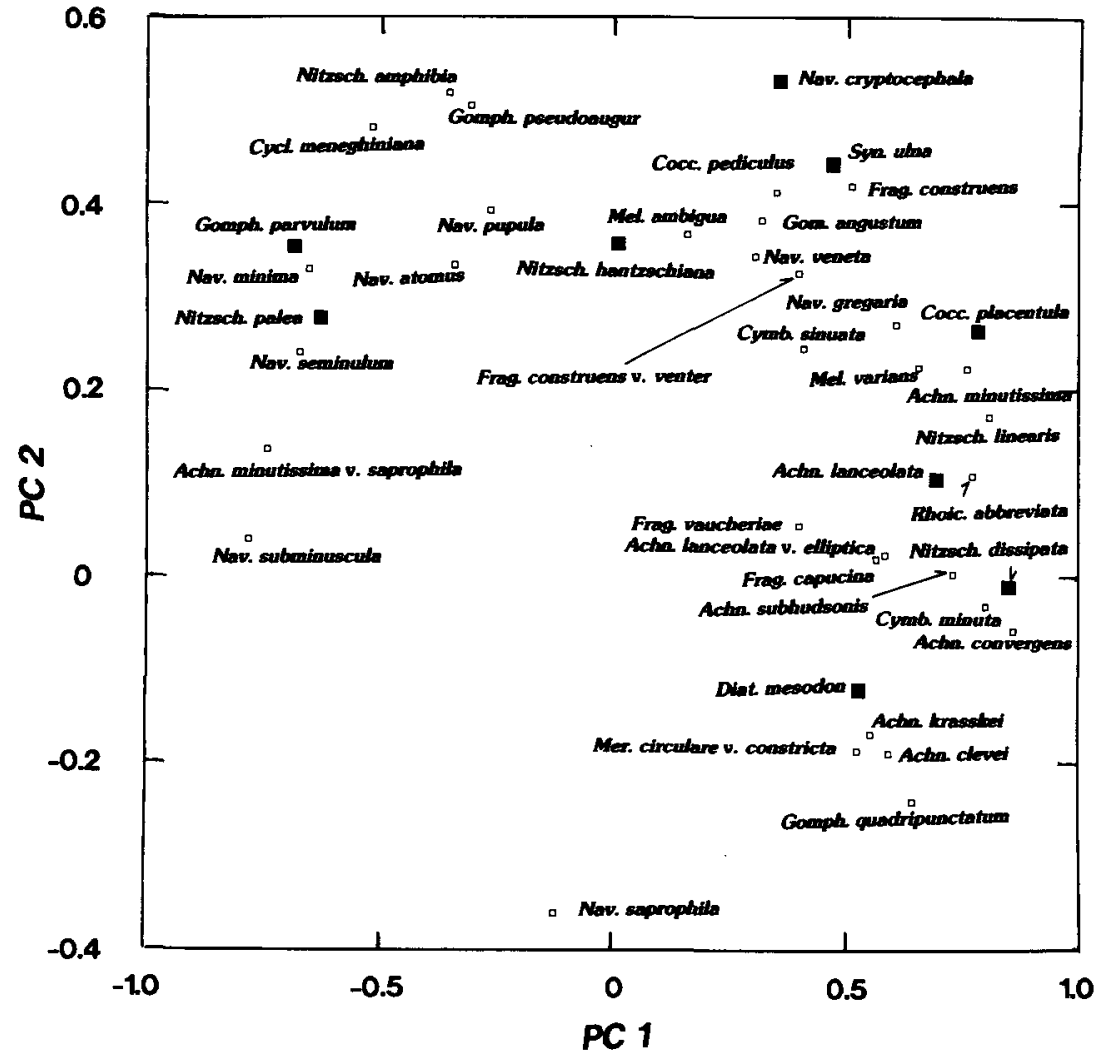

b)

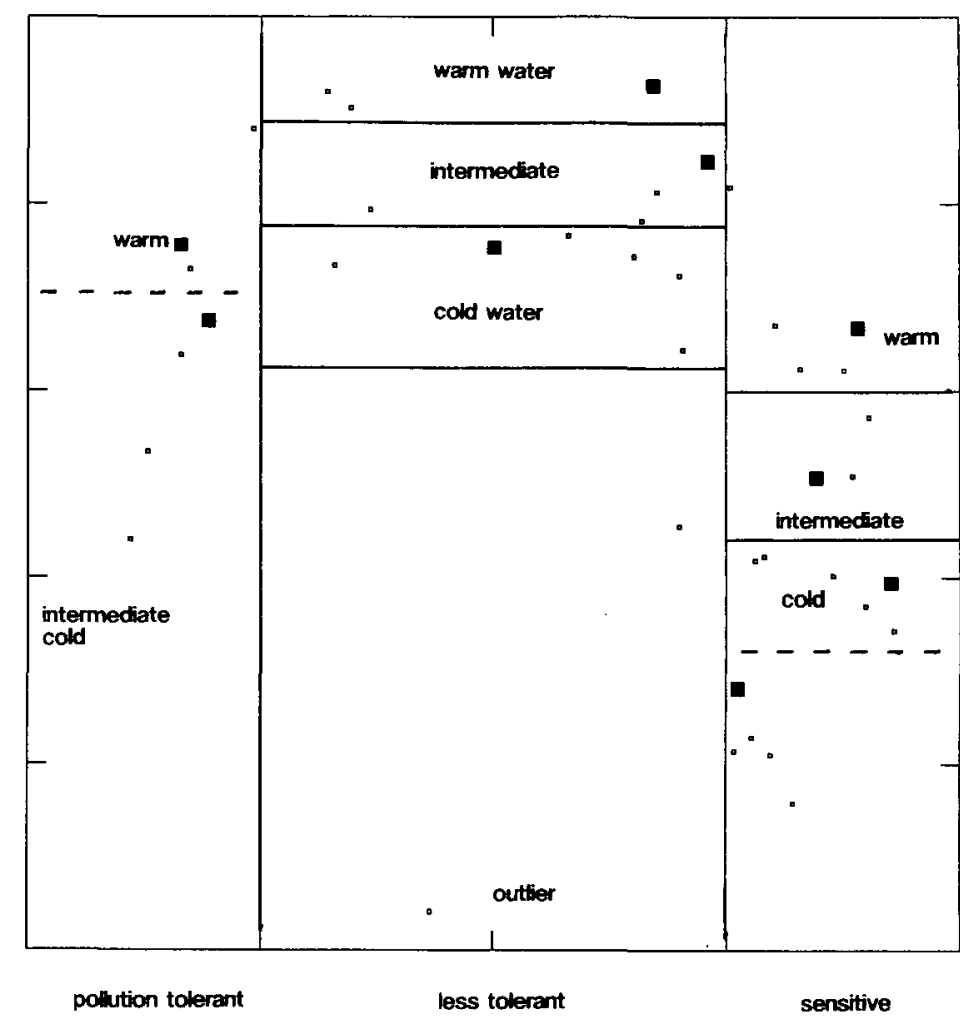

Fig. 5. a) Factor loadings of each taxon. Black squares indicate the taxa about which the results of the direct gradient analysis are shown in Figure 6. b) The way to evaluate the factor loadings of the second $\mathrm{PC}$ to determine the trend in water temperature. 

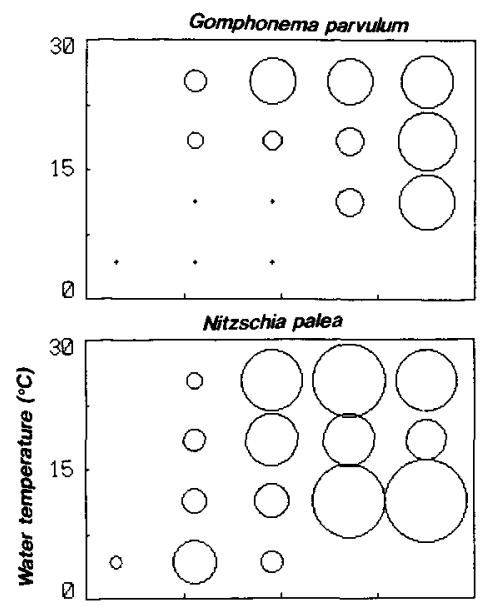

Diatoma mesodon

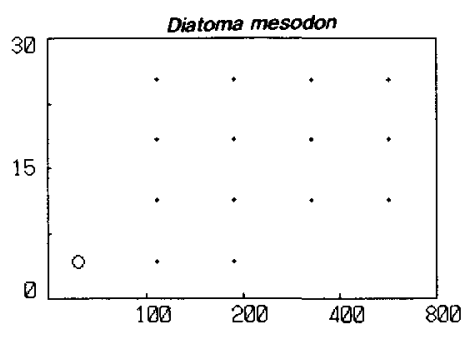

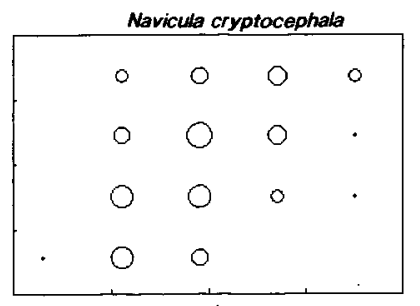

Synedra una

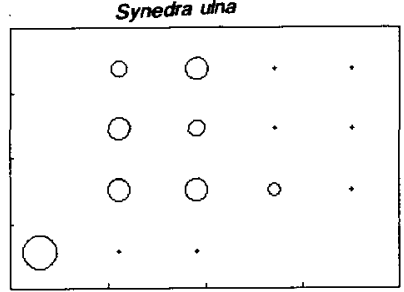

Nitzschia hantzschiana

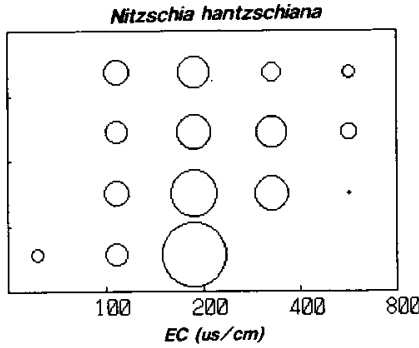

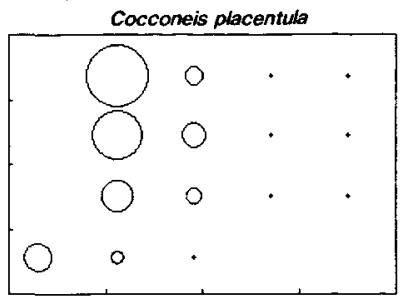

Achnanthes lancedata

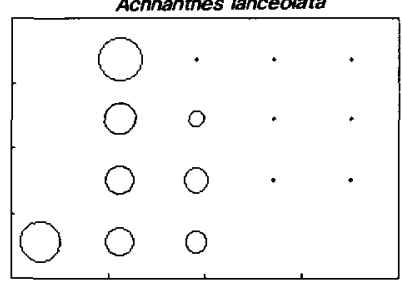

Nitzschia dissipata

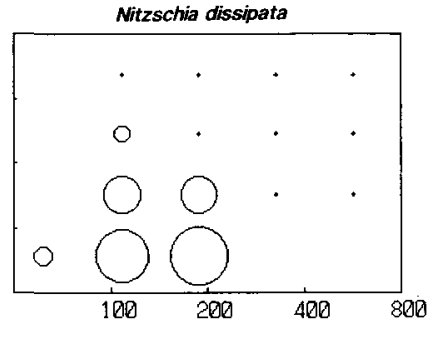

Fig. 6. The association between the relative abundance of major taxa and water conditions (EC and water temperature). The gradients of $\mathrm{EC}$ and water temperature are divided into five and four, respectively, and the average relative abundance in each section is indicated by the radius of circles.

a)

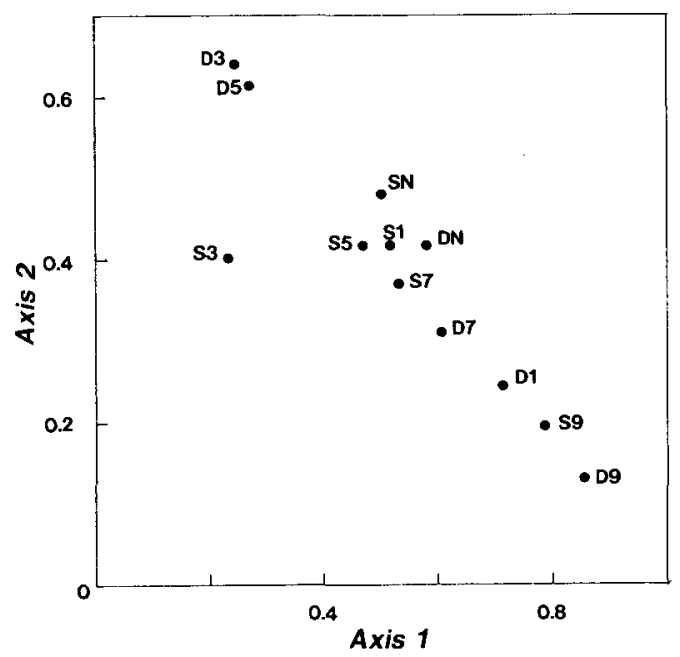

b)

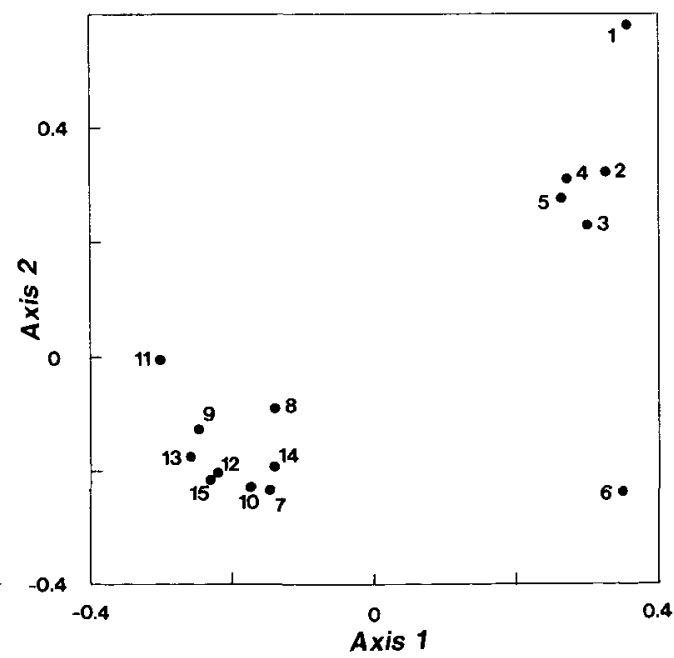

Fig. 7. The results of INDSCAL. a) The scatter diagram of the weight of each sampling condition (i.e., months and substrata). One to 9 and " $N$ " mean sampling months. The kind of substrate is indicated by " $\mathrm{S}$ " (stones) and " $\mathrm{D}$ " (dead leaves). b) The caluculated scaling of the first and second axis of the stations. The distance between the plots reflects the simimarity between diatom assemblages of the stations. 
tance with the chemical analysis. My thanks also to Dr. H. Kobayasi, President of the Japanese Society of Diatomology, for advice on the identification of diatoms.

\section{摘要}

\section{部分的に水質悪化がみられる河川における 珪藻群集の空間的および季節的変動}

部分的に水質污濁が進行している河川ではどの ような環境要因が付着珪藻群集に対して重要な影 響を及ぼすか，及び，個々の種と環境要因との間 にどのような関係があるかを，東京都の浅川に扝 いて調查した。主成分分析，個人差多次元尺度構 成法及び直接傾度分析により，得られたデータを 解析したところ，水質污濁，水温，付着基物の影 響が検出できた。浅川に扔いては，水質污濁が珪 藻群集の種組成に最も大きな影響を与える環境要 因となっており，付着基物の差による影響はき和 めて小さいものであった。また，付着基物は直接 に珪藻群集に影響を与えるほか, 周囲の水質や温 度に差を生じさせることにより群集に影響を与え るという間接的な影響が存在するらしいことが示 唆された。

\section{References}

BLOOM, S. A. (1981); Similarity indices in community structure: potential pitfalls. Mar. Ecol. Prog. Ser., 5: 125-128.

Bothwell, M. L. (1988): Growth rate responses of lotic periphytic diatoms to experimental phosphorus enrichment: the influence of temperature and light. Can. J. Fish. Aquat. Sci., 45: $261-270$.

BRAY, J. R. and J. T. CuRTIS (1957): An ordination of the upland forest communities of southern Wisconsin. Ecol. Mono., 27: 325-349.

Chessman, B. C. (1986): Diatom flora of an Australian river system: spatial patterns and envi. ronmental relationship. Freshwater Biol., 16: 805-819.

Clymo, R. S. (1980): Preliminary survey of the peat- bog hummell knowe moss using various numerical methods. Vegetatio, 42: 129-148.

DESCY, J. P. (1979): A new approach to water quality estimation using diatoms. Nova Hedwigia, Beiheft, 64: 305-323.

DigBy, P. G. N. and R. A. KempTON (1986): Muttivariate analysis of ecological communities. Chapman and Hall.
Feoli, E. and L. Froli-Chiapel.la (1980): Evaluation of ordination methods through simulated coenoclines. Vegetatio, 42: 35-41.

Flower, R. J. and A. J. Nicolson (1987): Relationships between bathymetry, water quality and diatoms in some Hebridean lochs. Freshwater Biol., 18: 71-85.

Fukushima, H., T. Ko-bayashi and K. Terao (1986): Correlation between water temperature and saprobic index of attached algae in river. Diatom, 2: 163-168 (in Japanese).

Gauch, H. G. (1982): Multivariate analysis in com. munity ecology. Cambridge University Press.

HILL M. O. (1973): Reciprocal averaging: an eigenvector method of ordination. J. Ecol., 61: 237-249.

Hill, M. O. and H. G. Gauch (1980): Detrended correspondence analysis: an improved ordination technique. Vegetatio, 42: 47-58.

Huttunen, P. and J. MeriLAinen (1983): Interpretation of lake quality from contemporary diatom assemblages. Hydrobiologia, 103: 91-97.

ICHIKAWA, A. (1980): Toshikasen no Kankyo Kagaku (Environmental sciences for urban rivers). Baifu-kan (in Japanese).

IMAIzUMI, T. and A. OKADA (1990): INDS3WAY (A computer program of INDSCAL for personal machine). Kyoritsu-shuppan.

KatoH, K. (1988): Multivariate analysis of periphytic diatom assemblage in the Asa-kawa River. Jpn. J. Water Treat. Biol., 24: 119-131 (in Japanese).

Kent, M. and J. Ballard (1988): Trends and problems in the application of classification and ordination methods in plant ecology. Vegetatio, 78: 109-124.

LAmpkin, A. J. III and M. R. Sommerfeld (1982): Algal distribution in a small, intermittent stream receiving acid mine-drainage. $J$. Phycol., 18: 196-199.

LANGE-Bertalot, H. (1978): Diatomeen-Differentialarten anstelle von Leitformen: ein geeigneteres Kriterium der Gewasserbelastung. Arch. Hydrobiol., Suppl., 51: 393-427.

LUDWIG, J. A. and J. F. RAYNoldS (1988): Statistical ecology. Wiley.

Millie, D. F. and R. L. Lowe (1983): Studies on Lake Erie's littoral algae; host specificity and temporal periodicity of epiphytic diatoms. Hydrobiologia, 99: 7-18.

Minchin, P. R. (1987): An evaluation of the relative robustness of techniques for ecological ordina. tion. Vegetatio, 69: 89-107. 
MUller-HAECKEl, A. and H. HÅKANSSON (1978): The diatomflora of a stream near Abisko (Swedish Lapland) and its annual periodicity, judged by drift and colonization. Arch. Hydrobiol., 84: 199-217.

Nofst, V., E. van der MaArel, F. van der Meulen and D. VAN DER LAAN (1989): Optimum-transformation of plant species cover-abundance values. Vegetatio, 83: 167-178.

Oksanen, J. and P. Huttunen (1989): Finding a common ordination for several data sets by individual differences scaling. Vegetatio, 83: 137-145.

Reiter, M. A. (1989): Development of benthic algal assemblages subjected to differing near-substrate hydrodynamic regimes. Can. J. Fish. Aquat. Sci., 46: 1375-1382.

SABAter, S. (1990): Composition and dynamics of a highly diverse diatom assemblage in a limestone stream. Hydrobiologia, 190: 43-53.

Steinman, A. D. and C. D. McInTire (1986): Effects of current velocity and light energy on the structure of periphyton assemblages in laboratory streams. J. Phycol., 22: 352-361.

Stevenson, R. J. (1983): Effects of current and conditions simulating autogenetically changing microhabitats on benthic diatom immigration. Ecology, 64: 1514-1524.

Sokal, R. R. and F. J. Rohle (1981): Biometry. Freeman.

TANAKA, S. and T. WATANABE (1990): The colonization process of a typical epilithic algal community, Homoeothrix janthina-Achnanthes japon- ica community, in a less polluted river in Japan. Jpn. J. Phycol., 38: 167-177 (in Japanese).

TER BRAAK, C. J. F: (1986): Canonical correspondence analysis: a new eigenvector technique for multivariate direct gradient analysis. Ecology, 67: $1167-1179$.

Tuchman, M. L. and R. J. Stevenson (1980): Comparison of clay tile, sterilized rock, and natural substrate diatom communities in a small stream in southeastern Michigan, USA. Hydrobiologia, 75: 73-79.

Varis, O., H. Sirvio and J. Kettunen (1989): Multivariate analysis of lake phytoplankton and environmental factors. Arch. Hydrobiol., 117: 163-175.

Watanabe, T. and N. Suzuki (1989): Effect of substrata on flora of attached diatom assemblage with reference to biological water quality assessment. Jpn. J. Limnol., 50: 129-137 (in Japanese).

WEHR, J. D. (1981): Analysis of seasonal succession of attached algae in a mountain stream, the North Alouette River, British Columbia. Can. J. Bot., 59: 1465-1474.

(Author: Kazuhiro Katoh, Department of Biology, College of Arts and Sciences, the University of Tokyo, Komaba 3-8-1, Meguro, Tokyo 153; 加藤和 弘, 東京大学教養学部生物学教室, $\bar{\top} 153$ 東京都目 黑区駒場 3-8-1)

Received: 5 December 1990

Accepted: 20 May 1991 